\title{
Peter Sherwood
}

\section{Language About Language: Notes On The New Hungarian Media Laws ${ }^{1}$}

\begin{abstract}
Following a landslide victory in the Hungarian elections of April 2010, the new Hungarian government embarked on a program of wide-ranging legislation, beginning with comprehensive changes to the laws on the media - both print and broadcast - from June 2010 onwards. These attracted widespread international attention and criticism. This paper considers only one limited aspect of this vast and enormously complex network of media legislation, in particular the deployment of language in some of the laws enacted, illustrating some possible consequences from a case that the NMMH (National Media Authority) attempted - unsuccessfully but revealingly - to pursue against the niche broadcaster Tilos Rádió in December 2010-January 2011. As this summary is being written in July 2011, following the end of Hungary's presidency of the European Union and thus its presumed retreat from the international spotlight, a slew of amendments to the media laws are being enacted, many apparently making them more stringent still (<http://www.bbj.hu/politics/house-passes-multitude-of-amendments-tomedia-law_58943\%29>).
\end{abstract}

My topic is a complex one, so that to say something worthwhile about it in the allotted time I shall limit myself to comments on the basis of what I know best: linguistics, that is to say, the scholarly study of language. In particular, I have a special interest in translation from Hungarian into English and, more generally, I have taught Hungarian language and culture in the English-speaking world for many decades. I should say also that I do not belong to, and never have belonged to, nor am I in any way associated with any political party or grouping in Hungary (or elsewhere), and I speak only as a scholar interested in, hopefully, shedding some light on certain issues. I shall perforce remain silent on many aspects of the media laws that have excited (often heavily politicized) debate, which must not be taken to mean that I consider them unimportant or less important.

Press freedom is a cornerstone of democracy, indeed: a precondition of other freedoms. Its importance and primacy is indicated, for example, by the fact that it is the topic of the First (rather than a numerically later) Amendment to the US Constitution and was also, in Hungary, the first of the points in the 1848 declaration by the March Youth (1. Kívánjuk a sajtó szabadságát, censura eltörlését/We demand the freedom of the press [and] the abolition of censorship). As a linguist I will be looking in particular at meaning, what the linguist calls semantics. For the linguist that term is not limited to word meaning; there is also sentence meaning and, for some linguists, pragmatic meaning ('it's hot in here' may be a plea to open the window). But here I will be generally talking about word meaning.

\footnotetext{
${ }^{1}$ A revised and slightly expanded version of a paper presented at the $36^{\text {th }}$ AHEA Conference, held at John Carroll University, Cleveland, April 14-17, 2011. The theme of the conference was "Whither Europe, Whither Hungary?" -- References to materials cited from the Internet were last checked on July 8, 2011.
} 
In fact, we can begin with the meaning of the word semantics itself. To the layman, the word semantics may have another sense, as in 'just semantics', implying usually that some kind of petty playing around with words or meaning is involved. It is one task of the linguist to identify this use of the word and carefully distinguish it from its other uses. It is important to point out that the linguist is primarily concerned with description, not prescription. That is to say, we describe what people do say, not prescribe what they should say. We do not, in the first place, talk about language in terms of 'good/bad', 'right/wrong' (these are terms from ethics), or 'beautiful/ugly' (terms from esthetics). However, it is (in my view, though this is not shared by all linguists) part of the linguist's remit to pay careful attention not only to what people do say but to their attitude to what they say, to what they consider the meaning of words to be when they reflect upon them. This brings us to the third use of the term semantics, one that is of key importance here: the lawyer's use. Legal definitions are obviously of great import in modern societies. For example, after 9/11, the owners of the Twin Towers wanted to claim insurance for the catastrophic damage. They had insurance for 'destructive "events", and the amount they were entitled to, depended on how many events there had been. Was the crashing of the planes into the towers one event or two? You might think this is an inappropriate or trivial thing to ask after such a terrible event (or events). But for each event the owners would receive 3.5 billion dollars. That's not 'just semantics'.

We see therefore that we have three different attitudes to language: the linguist's, the layman's and the lawyer's. I will be using the linguist's use of language to look at the other two uses.

We can now turn to the recent Hungarian legislation on the media, the so-called 'media package'. As this term suggests, this consists of several pieces of interrelated legislation and is so mind-numbingly complex that even Hungarian experts have had difficulty fully understanding its details. ${ }^{2}$ I want to stress that the first and, it can now be seen, highly programmatic step was taken as early as 28 June $2010^{3}$ when paragraph 61 of the old constitution, a simple general statement about the freedom of the press, was replaced by something more detailed. In particular, subsection 3 of this paragraph now stated that: A demokratikus közvélemény kialakítása érdekében mindenkinek joga van a megfelelö tájékoztatáshoz a közügyek tekintetében./In the interests of articulating democratic public opinion, everyone has the right to be provided with the "megfelelo" information regarding public affairs (this and other translations into English, and emphases, are mine, unless otherwise noted) ${ }^{4}$. Similar phraseology is used in Act 104 of 2010, passed on 9 November 2010, where paragraph 10 states: Mindenkinek joga van arra, hogy megfelelöen tájékoztassák a helyi, az országos, és az európai közélet ügyeiröl, a Magyar Köztársaság polgárai és a magyar nemzet tagjai számára jelentösséggel bíró eseményekröl./Everyone has the right to be informed in a megfelelö manner concerning public affairs at the local, national, and European level, ['and', or 'i.e.,'? - PS's insertion,

\footnotetext{
${ }^{2}$ For a very wide range of useful materials and links concerning the media package, see the Central European University's site at <http://www.cmcs.ceu.hu/node/297/>.

3 The date usually given is 6 July 2010, but the paragraph came into effect several days earlier: <http://mtvka.hu/ index.php?option=com_content\&view=article\&id=413:az-alkotmany-2010-julius-6-imodositasa\&catid=8:kozlemenyek\&Itemid=7T>

${ }^{4}$ Magyar Közlöny 2010. 114. szám. A Magyar Köztársaság Alkotmányáról szóló 1949. évi XX. törvény módosításáról. Az alkotmány 61. paragrafusa helyébe a következő rendelkezés lép...(3).
} 
no conjunction in the original] about events with significance for the citizens of the Hungarian Republic and the members of the Hungarian nation ${ }^{5}$. My reluctance to translate megfelelö(en) indicates part - but not all - of the problem. Would it translate as 'proper', 'adequate', 'suitable', 'appropriate', or something else again? But the real issue is that the Hungarian word prompts the question: minek/kinek feleljen meg? That is to say: appropriate or suitable for what purpose, and/or to or for whom? I have framed the question here in the linguist's terms: linguistically a simple way of stating what the meaning of a word is that it is the sum total of its possible uses. The layman's attitude to this meaning is endlessly debatable. The lawyer, however, cannot define what is megfelelö (or its possible English renderings). Such a term has no place in a legal document.

Another section of paragraph 10 of this same Act (moved in an amended form to paragraph 13 (1) in response to criticism from the European Union) has more wording of a similar kind, also criticized by, among others, the Organization for Security and Cooperation in Europe, which commissioned two special reports on the media package, one by Dr. K. Jakubowicz in September $2010^{6}$ and another, on the slightly modified legislation, by Dr K. Nyman-Metcalf in February 2011 ${ }^{7}$. This section now reads: $A$ médiatartalom-szolgáltatók összességének feladata a hiteles, gyors, pontos tájékoztatás a helyi, az országos és az európai közélet ügyeiröl, valamint a Magyar Köztársaság polgárai és a magyar nemzet tagjai számára jelentöséggel biró eseményekröl./It is the task of (the) media content-providers as a whole to provide trustworthy, rapid, (and) accurate information about public affairs at the local, national, and European level, as well as [note the difference here as compared with the formulation earlier in this paragraph - PS's insertion] about events with significance for the citizens of the Hungarian Republic and the members of the Hungarian nation. Here too the problem remains that the law imposes an overall obligation to provide information that is (for example) 'trustworthy' and 'accurate', without specifiying what trustworthiness and accuracy might be, either absolutely or in the context of the media 'as a whole' - another vague phrase. Nor is it specified who or what might decide which events have 'significance' - as if anyone could. These are not adjectives with a place in a legal document; they are termms one might use in an informal discussion. Finally, we might note that the formulation at the end of this quotation, as in the case of the previous one, draws a distinction between two - for the legislators clearly only partially overlapping groups of 'media consumers': citizens of the Hungarian Republic (i.e. irrespective of ethnonationality within the Hungarian Republic) and 'members' of the 'Hungarian nation' (i.e. - presumably - including 'ethnic' Hungarians irrespective of their physical location in the Danube basin - and perhaps even beyond?), thus doggedly keeping alive, even here, resentment at the nature of the post-World War I peace treaties.

Let me formulate the essence of the problem here: in a democratic society it is the right of the media to gather and disseminate information, news, and opinion. This right cannot

\footnotetext{
${ }^{5}$ Magyar Közlöny 2010. 170. szám. 2010. évi CIV. törvény. A sajtószabadságról és a médiatartalmak alapvető szabályairól, paragraph 10 .

${ }^{6}$ Cf. <http://www.state.gov/g/drl/rls/hrrpt/2010/eur/154428.htm>

${ }^{7}<$ www.osce.org/fom/75990>
} 
be made into a legal obligation to perform vaguely-defined things under the threat of punishment by massive fines. Of course, existing legislation should, and already does, cover hate speech and child pornography, for example. It is the introduction of an additional, complex, restrictive, and intimidatory layer of legislation, in scale amounting virtually to a government ministry that is not indicated and is not to be found in mature democracies with which Hungary would, presumably, wish to be compared.

To illustrate the way in which this legislation may be applied in the future, we can look at the affair of the Nemzeti Média és Hírközlési Hatóság (NMHH, which I translate and abbreviate as the National Media Authority or NMA) and Tilos Rádió. In the days just before last Christmas (2010), the Müsorfigyelö- és elemzőszolgálat of the NMA (that is, its department concerned with the monitoring and analysis of media content) wrote formally to Tilos Rádió, a small, moderately popular, youth-oriented, mainly musicbroadcasting independent radio service provider, claiming that it appeared to be prima facie in breach of the law ${ }^{8}$, in that Tilos Rádió broadcast, in the original and at a time when there was the possibility of an underage audience listening, a 'gangsta' rap by the rapper Ice-T, without issuing a statutory warning before the broadcast. Citing this paragraph of the law, the eight-page letter claimed basically that the text of the rap was "alkalmas a 16 éven aluliak fizikai, szellemi vagy erkölcsi fejlödésének kedvezötlen befolyásolására, különösen azáltal, hogy közvetlen módon utal eröszakra illetve szexualitásra (....)" /iable to influence in a negative way the physical, emotional or moral development of those under the age of 16, in particular by referring in direct terms to violence or sexuality (...). In its attempt to argue its case the letter referred, among other things, to research it had carried out specifically with this case in mind on the number of those in the relevant age-category in Hungary who had passed various levels of state language examinations in English, though it admitted that it could not say how many of those would be able to understand the rap's rather specialized language element. In a supplement to the letter, the entire text of the rap was reproduced, with what was claimed to be its Hungarian 'translation'. No reference was made either to the possible number of those who might actually have heard the rap, nor to the fact that rap is primarily a musical/rhythmic/poetic genre. (While I would not wish to 'defend' any specific rap, it is worth noting in passing that last year - 2010 - the prestigious Yale University Press published an Anthology of Rap, in the Foreword of which Henry Louis Gates, Jr., the leading US scholar of African American studies, calls the book "an essential contribution to our living literary tradition...[a] groundbreaking anthology [that] masterfully assembles part of a new vanguard of American poetry", ). Tilos Rádió not only defended itself robustly, but - crucially - made both the original letter and their reply to it available on the internet ${ }^{10}$, the latter also in an English translation ${ }^{11}$, thereby ensuring an extremely lively, and international, public media debate. Within days of the media package (and thus a "new" NMA) coming into force in January of this year - 2011 -, NMA

\footnotetext{
${ }^{8}$ Magyar Közlöny 2010, 202. szám 2010. évi CLXXXV. törvény a médiaszolgáltatókról és a tömegkommunikációról, paragraph 9(5)

${ }^{9}<$ yalepress.yale.edu/book.asp?isbn $=9780300141900>$

10 in Hungarian: (NMA to Tilos Rádió) Ice-NMHH-101213.pdf, and (Tilos Rádió to NMHH) Ice-Tilos101229.pdf

11 <http://radia.posterous.com/hungarian-media-regulator-attacks-tilos-radio>
} 
spokeswoman Karola Kiricsi announced on its brand-new blog (!) that she wanted to streamline the operations of the NMA - and abandoned the T-Ice case ${ }^{12}$. While she emphasized that the process against Tilos Rádió had been instigated under the "old" media law, and claimed that media coverage had tried to obscure this, this was disingenuous to the extent that the new media package retains these particular provisions, which remain, with the other vaguely formulated language in the media package - some of the terms of which I have outlined above - as a sword of Damocles hanging over broadcast media content.

No one would wish to minimize the dangers of exposing minors to unacceptable content, of course, and their protection against excessive violence or sexual content in the media remains one of the problems that have proved virtually intractable in our time (which is not to say that strenuous attempts to solve it should not continue to be made) $)^{13}$. Here I would just like to pick out two angles on this case that seem to me most relevant to the issue of press freedom in Hungary, in the broadest terms.

On the one hand, as in the rather more important, ongoing case of the Middle East and North Africa, the new media have played an important role in the matter of NMA vs. Tilos Rádió. In particular, they highlighted the nature of the NMA's operations and attitudes, the time and expense involved in ensuring - to mention only one irony - that thanks to its heavy-handed and absurd pursuit of this case, a far greater number of Hungarians came to know about this rap than had ever heard it (or understood its linguistic content) when it was originally broadcast. Even more to the point, the very media the NMA is attempting to control has a far greater reach and power than the NMA has had the imagination to envisage. Factors such as globalization, the Internet, the spread of social media, extensive travel and mobility within society, and - not least ever-increasing knowledge of at least a lingua franca-type of English is showing that it is becoming increasingly impossible to insulate Hungary from the world outside it. (A similar attempt to pull the wool over the eyes of the non-Hungarian-speaking world can be seen in the way the Hungarian government passed an English translation of the new Hungarian constitution to the EU: apart from a number of errors of translation, some apparently deliberate, the copy sent to the EU lacked the constitution's so-called 'Preamble' [in fact, the symptomatic and in every sense more faithful translation of what in that document is called Nemzeti Hitvallás would be 'National Declaration of Faith']. These errors of commission and omission were immediately picked up and corrected/supplied by civic organizations in Hungary and posted on the Internet as well as to the EU. ${ }^{14}$ )

On the other hand, we must note the comments of Mr. Frank La Rue, the United Nations Human Rights Council's special investigator on freedom of expression, on his visit to Budapest in early April 2011. Even after amendments to the law made at the request of

\footnotetext{
12 <http://www.mno.hu/portal/759143>

${ }^{13}$ cf. for example Report dated April $6^{\text {th }}$, 2007, before the Federal Communications Commission, Washington DC 20554, in the Matter of Violent Television Programming and its Impact on Children, which was unable to offer any definitive advice on the issue to the US Congress.

14 <http://tasz.hu/en/freedom-of-speech/misleading-translation-and-serious-problems-hungarian-draftconstitution>
} 
the EU, Hungary's media regulations, he said, "still fall short of the required benchmarks." He went on to say that attempts by governments to dictate balanced media coverage often lead to censorship. "Every time we hear about balanced coverage or objectivity of the press...it inevitably becomes, with time, a form of censorship, regardless of what the original motivation was," La Rue said. "The press is accountable...to the public and never to the state and much less to the government." (Washington Post, April $\left.5^{\text {th }}, 2011\right)^{15}$.

Mr. La Rue's host on this visit was Mr. Zoltán Kovács, secretary of state for "kormányzati kommunikáció"/government communications (?). He asserted, yet again, that the media laws were fully democratic and did not require alteration. In particular he made the following claim, with which I would like to conclude this language-centric note on the media package: A specifikus helyi körülmények ismeretére van szükség a magyar médiatörvény megértéséhez/To understand the Hungarian media law it is necessary to have knowledge of the specific local circumstances. (168 óra online, April 6th, 2011) ${ }^{16}$. This claim to Hungarian exceptionalism lies at the very heart of the matter. What exactly are these 'specific local circumstances' and why should it be necessary to have knowledge of them in order to understand a Hungarian law? We are, let us remember, hardly talking about Petoffi's poetry here. Will this condescending and at the same time exceptionalist attitude encourage the outside world to take the interest in Hungarian life and culture that many Hungarians, presumably even Mr. Kovács, would deem desirable? As long as a Hungarian secretary of state for communications considers it impossible for non-Hungarians to understand a Hungarian law, it seems to me that the answer to the question posed by the title of this conference ${ }^{17}$ will remain: at least as regards freedom of the press, the present Hungarian government is taking Hungary down a path opposite to that chosen by Europe.

${ }^{15} \mathrm{cf}$. 〈http://wwww.mandiner.hu/cikk/20110405_ensz_raportor_problemas_a_mediatorveny>

${ }^{16}<\mathrm{http}: / / \mathrm{www} .168 \mathrm{ora} \cdot h u /$ itthon/ensz-kulonmegbizott-a-mediahatosag-legyen-fuggetlen-intezmeny-

73332.html?fejezet=1>

${ }^{17}$ See fn. 1 